\title{
ECONOMIC RELATIONSHIPS BETWEEN THE MEMBERS OF VIRTUAL ENTERPRISE
}

\author{
V. Belak, M. Kolakovic, B. Kovacevic \\ University of Zagreb and Split, CROATIA \\ belakv@oliver.efst.hr, marco@pravo.hr, bkovac@efzg.hr
}

One of the key elements of the operation and development of a virtual enterprise is the establishment of economic relationships between its members. The members of a virtual enterprise may be firms, parts of firms or individuals whose relationships are based on contracts.

Economic relationships between the members of a virtual enterprise are based upon flexible long-term contracts and they direct themselves toward distribution of the results achieved together. The base of division of the joint results presents joint planning of revenues and expenditures, and taking part in shared revenue or shared profit. . According to this, the aim of this paper is the development of the accounting models of economic relationships in virtual enterprises that will ensure the decrease of total costs and increase of the efficiency of virtual enterprise.

\section{INTRODUCTION}

The concept of the virtual organization and the mechanisms used to form virtual enterprises are not in themselves new. However, the degree of use and intensity of cooperation together with the degree of using new information technology and new kind of business are of recent date.

Any sample of a virtual enterprise uses one or more of the existing organizational mechanisms such as: partnership, joint venture, strategic alliance, cooperative agreement, royalty or license, outsourcing contract, web etc. Of these organizational forms, only the web is a completely new concept (Goldman et al., 1995, p.208).

The task of a virtual enterprise is to make links of core competences of different firms or individuals with specific skills in order to achieve a particular goal.

Major characteristics of virtual enterprises are:

- Concentration on linking core competencies of potential or regular members of virtual enterprise

- Direction towards wishes and satisfaction of customers

- Foundation on information technology (Davidow and Malone, 1992)

- Nonexistence of hierarchy borders are not fixed

- Customer's perception of only one vendor (Piontek, 1998)

- Dependence on possible appearance of opportunism

- Based on trust (Rajiv, 1999)

- Based on group of contracts (Aoki, Gustafson and Williamson, 1990)

The original version of this chapter was revised: The copyright line was incorrect. This has been corrected. The Erratum to this chapter is available at DOI: 10.1007/978-0-387-35585-6_68 
Virtual enterprises generate value not only from their virtual existence but from their operations as well (Grenier and Metes, 1995; p. 8). Accordingly, one of the major conditions for the existence of a virtual enterprise is the motivation of its members for work together, without any significant problems in their mutual relationship.

One of the key elements of operation and development of a virtual organization is the establishment of economic relationships between their members. An optimal model of economic relationships should ensure motivation for work together and remove the appearance of opportunism.

Thus, accounting models of economic relations in a virtual organization should be developed in order to ensure fair fees for the members of a virtual enterprise, in terms of invested resources and efforts made to achieve joint results. Transparency and fairness of accounting calculations should ensure confidence, motivation and content of virtual enterprise members.

The aim of this paper is to investigate and suggest major accounting models of economic relations in a virtual enterprise, which may be used in practice.

\section{TYPOLOGY OF ECONOMIC RELATIONSHIPS IN A VIRTUAL ENTERPRISE}

Although the concept "virtual" has a connotation of unreal, the resources that are invested in the realization of products and services in a virtual enterprise as well as the obtained financial results, are very real. This is why the members of a virtual enterprise take care of the compensation they receive for invested resources and efforts made in joint work. Therefore, determining participation in total financial results presents the basis of economic relationships in a virtual enterprise. A virtual enterprise may be strengthened and developed by a good selection of models of economic relationships. However, it may be destroyed by the conflicts among its members, which occur during the negotiation regarding compensation for participation in joint production or for services accomplishment.

So, the selection of an optimal model of economic relationships between the members of a virtual organization presents the key of its operation and existence.

Economic relationships between the members of a virtual enterprise may be established in different ways. Anyway, three basic models can be pointed out:

a) Market relationship model

b) Joint revenue model

c) Joint profit model

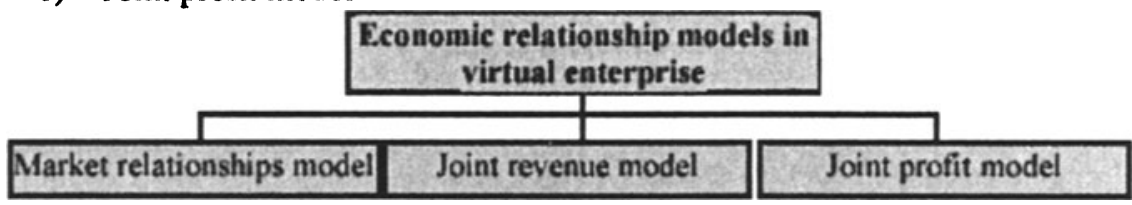

Figure 1 - Economic relationship models in a virtual enterprise

Each of the above mentioned models of economic relationships could be developed through a number of variants, depending on practical needs. Combination of models can be used as well. Consequently, the paper goes on to consider the basic models of economic relationships together with their major modalities. 


\section{MARKET RELATIONSHIPS MODEL IN A VIRTUAL ENTERPRISE}

A model of market relationships in a virtual enterprise is based on pre-fixed and defined contracts on mutual deliveries and their compensations. Major characteristics of this model are the following:

- Contracts are fixed and previously defined

- Compensations are based on market prices

- The leading firm takes the risk and the remaining profit belongs to it

- The leading firm has the right to choose cheaper suppliers at the open market The market relationships model can be provided in two basic modalities, i.e. as:

a) Full market relationships model

b) Modified market relationships model

(a) The full market relationships model between the members of a virtual enterprise is based on market prices of mutual transfers. The leading firm pays contract prices of delivery to its suppliers, regardless of the realization of products and services and their respective revenue. In this case the enterprise is considered to be virtual because of the large extent of engagement of the capacities of virtual enterprise members with respect to the leading firm. The leading firm, in this case, only performs the strategic functions of business while other resources are provided from other participants. Thus, the leading firm may have only a few employees who take care of management and organization of a virtual enterprise as well as of product design and development, financing and sale.

An organizational scheme of virtual enterprise based on full market relationships from experience in Croatia is shown on the figure 2. The example presents the production of soft drinks. The leading firm has only three employees and an office. They control the design and development of products, management and finance. All other resources and capacities are purchased at the market. Production takes place only during the summer season while in wintertime it is interrupted.

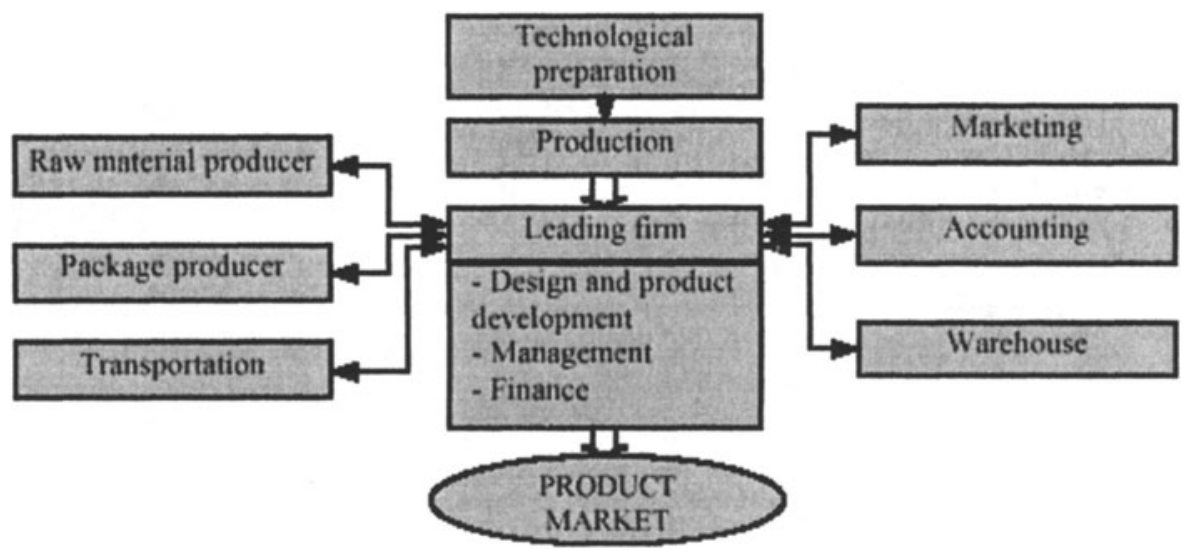

Figure 2 - Virtual enterprise based on full market relationships

The virtual enterprise, shown in figure 2, bases its competition on low costs, because there are practically no fixed costs. 
(b) Modified market relationships model in virtual enterprise permits corrections of market prices of mutual deliveries that are based on common plan of business and long-term delivery contracts. A decrease of market prices is based on decreasing transactional costs and on better use of capacities. Better use of capacities is based on mutual middle term and long-term plans, together with the help and transfer of knowledge and technology provided by the leading firm to the other members of the virtual enterprise.

Economic relationships between the members of a virtual enterprise in modified market relationships models are much stronger than in full market relationships models. Hence, this model provides the possibility to accept common risk of assets payment from products and services sale.

\section{JOINT REVENUE MODEL IN A VIRTUAL ENTERPRISE}

The model of sharing joint revenue between the members of a virtual enterprise implies stronger economic links between the members. The basic problem of economic relationships in the joint revenue model is how to define ways of sharing revenue. According to that, revenue that belongs to every member of virtual enterprise can depend on ways of sharing joint revenue, and also on:

a) Certainty of the revenue (product or service for known customer)

b) Uncertainty of the revenue (product or service for unknown customer)

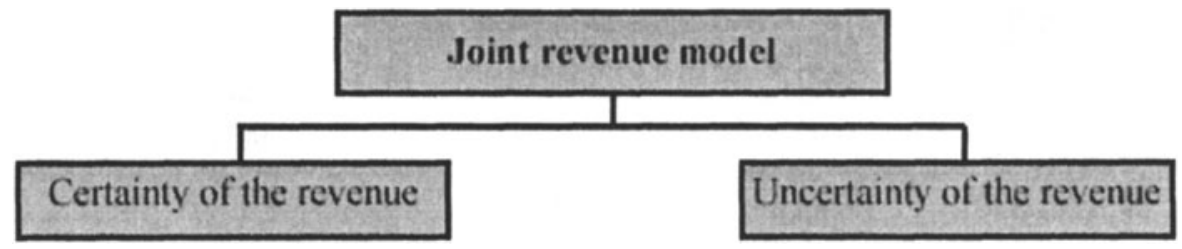

Figure 3 - Joint revenue model in a virtual enterprise

(a) When operated by order for a known customer, revenue is certain, because it is regularly contracted in advance. In such a case, the virtual enterprise is being set in motion in the moment the order is received. However, the participation of virtual enterprise members in joint revenue should be contracted separately. To solve this problem it is possible to apply different forms of models out of which the most interesting are:

a1) determine fixed share in revenue for all members of virtual enterprise on basis of previous offers according to which the selling price is formed,

a2) determine fixed share in joint revenue on basis of fitting into an assigned selling price,

a3) sharing joint revenue on the basis of activities.

(a1) If the selling price is formed on the basis of the previous offers of all the members in the virtual enterprise and as such accepted on the market, then sharing mutual revenue is simple. The revenue share of every member is known in advance, by amount and percentage. 
Possible losses on the selling price, due to disregarded deadlines or inadequate quality of the business that has been done, may be borne with solidarity by the members of a virtual enterprise, in respect to the percentage of their share in the revenue. Of course, this is to be done when there is not a particular responsibility of one or more members for this loss. When the members who caused it are known then the loss may come to their own charge.

(a2) Fixed share defining in joint revenue, on the basis of fitting into the assigned selling price, requires more negotiation between the members of a virtual enterprise together with more complicated procedures than in the situation described in (a1). There are no problems if the sum of the offered prices provided by the members of a virtual enterprise is smaller than the assigned market price. Here the remainder of the revenue is divided on the basis of the share of single prices.

However, practice shows that it is quite frequent that the sum of single prices, offered by the members of a virtual enterprise, exceeds the assigned selling price. If the members agree to lower all single prices for equal percentage and thus fit into the selling price then the procedure is over. However, that approach is not good, because in the future it motivates individual members of the virtual enterprise to give unrealistically high prices in order to gain a bigger share in the joint revenue, after linear decreasing is finished.

Therefore, it is more appropriate to analyze together the reality of all offered individual prices, to make sure what are the realistic individual prices, and after that linear decreasing of all offered prices can be applied in order to fit into assigned market price.

While defining real individual single prices one should, whenever possible, start from the market prices of the same or similar products and services. Another possibility is to offer the same job to a number of potential members of a virtual enterprise.

(a3) The share of joint revenue on the basis of activities stands for the division of the whole assignment into main activities together with revenue share on respective activities. This is to be done before the assignment is shared on the members of a virtual enterprise. If necessary, main activities may be further divided into subactivities the value of which is also defined on the basis of their share in the revenue.

Each participant in a virtual enterprise gets the share, which is "earned" by doing some activities or subactivities. In case joint costs of a virtual enterprise appear i.e. the costs, which are not included in the activities or the ones that are to be paid to the suppliers, they are subtracted from the revenue before the share of the joint revenue is done.

Fig. 4. shows how main activities of the task may be defined, how the members of a virtual organization do them and how joint revenue may be shared.

The model of joint revenue share on the basis of accomplished activities and subactivities, whose value is determined by their share in the revenue, enables " share trade" in the course of business operations. For example, if the company A does some services for the company B, which are marked like subactivities with value of 2,5\% revenue shares, there will be no bill to send out, but just an operation in which the firm A gains another 2,5\% of shares in joint revenue, which is given to it by firm $B$. 


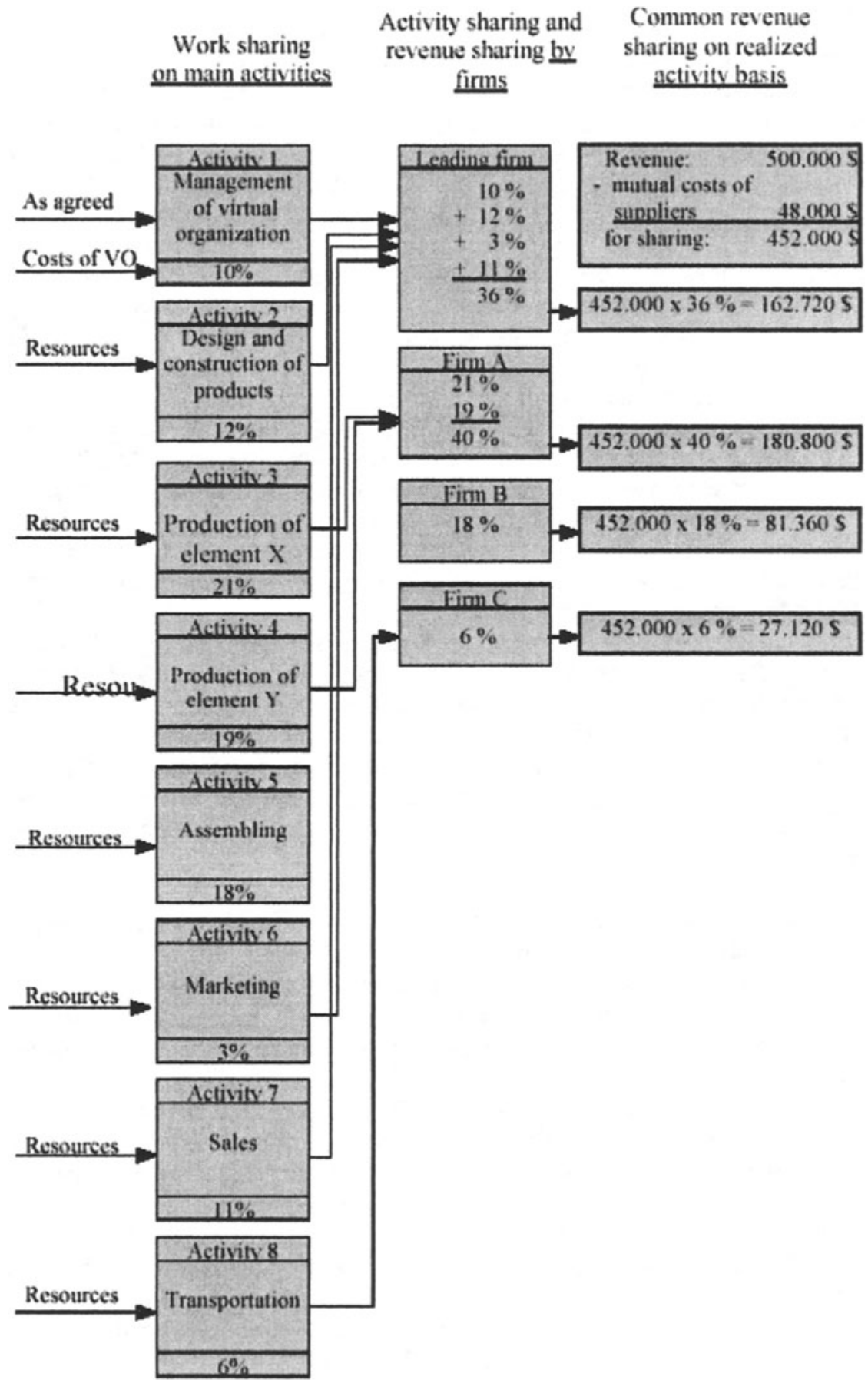

Figure 4 - Main activities, their realization by members of virtual enterprise and sharing joint revenue 
(b) In a situation in which production or services are for unknown customer and when the revenue is uncertain, it is possible to point out two basic models:

b1) model of determination of fixed share in potential revenue

b2) contribution margin model

b1) The determination of the fixed share in potential revenue is based on the definition of the activity of each participant in the virtual enterprise and the resources that are being sacrificed. In the framework of this model, the members' revenue depends on achieved selling prices, the quantity of selling and on share in joint revenue. Profits or losses will depend on the amount of earned revenue and on the control of the own costs.

b2) The model of contribution margin stands for the share of the jointly achieved revenue on the basis of acknowledged variable costs i.e. their participation in the revenue.

The model of contribution margin implies careful planning of variable costs. However, it might occur that a member manages to prove that real variable costs had to be higher than planned. Under these circumstances other members may admit correction and recalculate all shares.

When the business is done for unknown customer, the coverage of fixed costs and profit realization for all members of the virtual enterprise depends on the quantity of sold products and services.

\section{JOINT PROFIT MODEL IN A VIRTUAL ENTERPRISE}

The model of joint profit share in a virtual organization is based on the assumption that the profit will first be used to cover all known costs and then it will be shared between the members on the basis of previously agreed principles.

The members can share the profit in two main ways:

a) With respect to previously defined percentage, regardless of resource investments,

b) With respect to resource investments.

(a) The share of the joint profit by previously defined fixed percentages may be a suitable model when joint and individual costs can be predicted and clearly defined. This model is most often used in a situation when the leading firm accepts most of the resource investments while participation of its members is based mainly on intellectual work. Here, revenue, costs and profit may be known in advance but they may be uncertain if business is done for an unknown customer.

(b) The model of joint profit share with respect to the resource investments is applicable in situations when resource investments of each member of a virtual organization cannot be enough precisely planned in advance because the engagement of resources depends on the accomplishment of unplanned activities. In this case acknowledged costs of invested resources of all members of a virtual organization are subtracted from the revenue while the profit is distributed with respect to the shares in invested resources. 


\section{CONCLUSION}

The key for the functioning of every virtual enterprise, which consists of more members, is establishing an optimal model of economic relationships between them. Defining shares of its members in jointly realized financial result presents the base of economic relationships in a virtual enterprise.

Economic relationships between members of a virtual enterprise may be established in different ways. The three basic models of relationships are presented in this paper: the market relationships model, the model of division of joint revenue and the model of division of joint profit.

It cannot be said that the certain model is generally better than the other. The choice of an optimal model depends on the concrete market situation in virtual enterprise. If the connections between the members of a virtual enterprise are weaker and subjects of transfer of market products or services, probably the most adequate will be the model of market relationship or model of modified market relationships. The model of division of joint revenue or joint profit requires tighter connection between members of virtual enterprise and greater mutual confidence than the model of market relationship. This paper presents basic characteristics of different types of models of economic relationships, which are to be further elaborated for the purpose of application in real practical situations.

\section{REFERENCES}

1. Aoki, M., Gustafson, B. and Williamson, O.E.: "The Firm as a Nexus of Treaties", Sage Publications, London, 1990.

2. Arnold, O: "Virtuelle Unternehmen als Unternehmenstyp der Zukunft?", HMD, Vol. 32, No. 185, 1995, p. 8-23.

3. Belak, V., Kovacevic, B. and Kolakovic, M.: "Activity based approach in designing of virtual organization", Proceedings of the $11^{\text {th }}$ International DAAM Symposium, Opatija, Croatia, October 19-21, 2000, p. 23-24.

4. Belak, V., Kovacevic, B. and Kolakovic, M.: "Intellectual Capital as a Base for Designing a Virtual Organization - the Case of Croatia", Proceedings of the Business \& Economics Society International 2001 Conference, B\&ESI, July 22-26. 2001, Paris, France

5. Byrne, J.A.: “The Virtual Corporation”, Business Week, 2/93, p.p. 98-102.

6. Camarinha-Matos, L.M. and Afsarmanesh, H.: "Infrastructures for Virtual Enterprises“, Kluwer Academic Publishers, 1999.

7. Christie, P.M.J. and Levary, R.R.: "Virtual Corporations: Recipe for Success", Industrial Management, Vol. 40, No. 4, 1998, p. 7-11.

8. Davidow, W.H. and Malone M.S.: "The Virtual Corporation: Structuring and Revitalizing the Corporation for the $21^{\text {st }}$ Century", New York, Harper Business, 1992.

9. Giertz, E. "Measuring Success - Identifying Performance Indicators", Celemiab International AB, Malmoe, Sweden, 2000.

10. Goldman, S.L., Nagel, R.N. and Preis, K.: “Agile Competitors and Virtual Organizations”, Van Nostrand Reinhold, Inc., New York, 1995.

11. Gora, W. and Scheid, E.M.: "Organisation auf dem Weg zur Virtualität", iz "Virtuelle Orgaisationen im Zeitalter von E-Business und E-Government", Springer Verlag, 2001.

12. Goranson, H.T.: "The Agile Virtual Enterprise", Quorum Books, 1999.

13. Grenier, R. and Metes, G.: "Going Virtual", Prentice Hall, Inc., New Jersey, 1995.

14. Hedberg, B., Dahlgren, G., Hansson, J. and Olve N. G.: "Virtual Organization and Beyond", Wiley and Sons, New York, 1997.

15. Oates, D.: "Outsourcing and the Virtual Organization", Century Business, 1998.

16. Piontek, J.: "Kooperationsform der Zukunft", Logistik Heute, Vol. 20, No.5, 1998, p. 43-48.

17. Rajiv, S.: "The Role of Trust in Outsourced IS Development Projects", Communication of ACM, No. $2 / 99$, p. $80-86$.

18. Savage C.M.: " $5^{\text {th }}$ Generation Management", Butterworth-Heinemann, 1996. 